\title{
ASSESSMENT OF BUSINESS CONDITIONS BENEVOLENCE: CASE OF OCCUPATIONAL SAFETY AND HEALTH SERVICES
}

\author{
Živilė TUNČIKIENĖ ${ }^{1}$, Rolandas DREJERIS ${ }^{2}$ \\ ${ }^{1,2}$ Department of Social Economics and Management, Faculty of Business Management, \\ Vilnius Gediminas Technical University, Sauletekio al. 11, 10223, Vilnius, Lithuania \\ E-mails: ${ }^{2}$ zivile.tuncikiene@vgtu.lt (corresponding author); ${ }^{2}$ rolandas.drejeris@vgtu.lt
}

Received 23 November 2016; accepted 18 May 2017

\begin{abstract}
The aim of the article is to find solutions for assessing the benevolence of business conditions in existing circumstances. The business situation in the area of occupational safety and health (OSH) services was investigated in order to assess possibilities to start up this kind of commercial activity. The proposed methodology of assessment is tested only on the basis of occupational safety and health services, but the sequence and the content of the provided actions for assessment may be also used for initiating any other kinds of business. Systematic approach has been applied to searching for solutions primarily to assess general aspects which are then narrowed down to the assessment of smaller issues. Suitability of theoretical decisions has been tested in real business conditions. In order to assess the benevolence of business conditions in the current situation before starting up a certain business, the article provides certain assessment measures and their application techniques. Applying the chosen methodology may help to start a new business smoother, develop the existing one and thus achieve better results.
\end{abstract}

Keywords: business conditions, factors of external and specific environment, benevolence, assessment, startup, development, services.

JEL Classification: M130, M190.

\section{Introduction}

Economic freedom is defined as a fundamental right of individuals to manage their property and benefit from it, and also to guide their work in the desired direction. The constitutions of many countries include the provision that every person is quite free to choose a desired activity to earn a living: salaried job or own business. Governments of different countries generally encourage business start-ups (Helmers, Rogers 2010; Kandel et al. 2011; Blank, Dorf 2012; Feinleib 2012; LEM 2014; Zoltan et al. 2015). In Lithuania, for example, there are various training courses and a range of various incentives available for business pioneers. It is noted that a goal of a modern business is not only financial benefits, but also persons' recognition in the public, staff's wellbeing and satisfaction of self-expression (Kurzynski 2012). According to a research conducted by RAIT market research company (2014), the majority (40\%) of Lithuanian 
people identified a wish to be free and independent as the main reason for starting up own business, $26 \%$ of them emphasized a desire to earn more, and $6 \%$ reported selfexpression as a main motive. Today, each company is more likely than ever before even to fight for every customer (Krämer et al. 2016). Compete on price alone is no longer sufficient (Panagiotakopoulos 2013; Krämer et al. 2016). An important role in this case is also played by producing high quality products, paying due attention to customers' needs, good image and reputation of a company. According to the information of the Department of Lithuanian Statistics (DLS) for 2016, in 2015, bankruptcy proceedings were initiated for 1638 economic entities. The causes of bankruptcy also were identified: lack of working capital, inadequate management. Such consequences indicate that companies were not properly prepared for starting a new business and/or developing the existing one. In light of today's challenges, there is an even greater need for solving the problem which is raised in this article. A question therefore arises how to start a business and how to assess benevolence of business conditions in the current situation? According to Onel and Avinandan Mukherjee (2015), the company's business environment consists of a totality of variables and different content factors which need to be assessed, and decisions about future activity should be strictly based on the results of the assessment. Unfortunately, there has been so extensive studies conducted so far that would characterize the appropriate business creation situations. So, the aim of the article is to find solutions for assessing the benevolence of business conditions under existing circumstances for starting up a new business.

The ability to compete for producers of goods and service providers on a global level depends on social economic policy. Countries and businesses compete in international markets (Akram et al. 2011; Daryanto et al. 2013). Competition among countries tends to focus on attracting foreign direct investment (FDI) (Szkorupová 2015). Accordingly, business conditions can be determined for a country, for a region and for an individual location (Soltes, Stofkova 2016).

\section{Theoretical approach to business conditions benevolence assessment}

Business initiation is quite a difficult task not only for newcomers, but also for professionals, because of rapidly changing business conditions in a modern economic globalization. Any state shall endeavor to create the most favorable conditions for business start-ups and activity development (Akram et al. 2011; Aruoba et al. 2012; Mitzner 2016). Therefore, the first question is the choice of business location that predestines the results of assessment of business conditions benevolence. Business conditions are like country's potential and strengthening it may lead to higher competitiveness. The degree of competitiveness not only determines business conditions, but also the de facto possibility to implement them (Akpinar et al. 2017). So, business conditions show how easily and how quickly companies (or individuals) can achieve significant results (achievements can also show the level of people entrepreneurship) and allow assessing market penetration possibilities.

Some research studies of business conditions were carried out already in the 19th century. The indexes were based on a limited number of separate indicators, such as 
changes in interest rates, price levels and others. The use of business conditions measuring indexes is also popular today. Most of them are based on confidence indexes for consumers, producers and individual economic activities, but in today's business conditions concept has become much wider (Adomako, Danso 2014). Knowledge of the benevolence of business conditions, business opportunities and threats in a country at issue can help in making a decision to begin one or another activity. Typically, business conditions are first tested in a home country and, if they are unfavorable, then more favorable business conditions are searched in other countries (Gammeltoft et al. 2010). Assessing the benevolence of business conditions in a country is the first step in making the decision about starting up any commercial activity or even about developing the existing business.

The World Bank $(2014,2015)$ uses the Doing Business "model for assessing benevolence of business conditions" covering 10 complex criteria. The assessment of benevolence of business conditions according to the "Doing Business" index combines such areas as starting a business, construction permits, hiring, registering property, getting a credit, protecting investors, paying taxes, trading across borders, enforcing contracts, and interrupting business. The World Economic Forum's (2015) global competitiveness index proposes calculation which combines all of the available statistical information, including data of subjective surveys. Hence, such findings are based on qualitative assessments provided by the experts participating in the forum (Ketels 2013). According to experts of the Heritage Foundation, economic has a definite link with some positive social factors (Samoška 2011; Heritage Foundation 2013, 2014, 2015). The Economic Freedom Index is calculated based on ten economic freedom factors (business freedom, trade freedom, fiscal freedom and government spending, monetary freedom, investment freedom, financial freedom, property rights, freedom from corruption, and labor freedom). The factor is measured on a $0-100$ scale, where 0 is the worst score.

A complete set of aspects with regard to the benevolence of business conditions could include a SWOT analysis. Most companies systematically scan the country's business environment looking for possibilities to develop potential capabilities that would give the flexibility to deal with threats and opportunities (Hamlin 2012).

When it is decided that conditions in some country are suitable for business activity, it is necessary to decide what kind of business is the best (Cole 2015). Business direction may depend on the circumstances in the market and, in some situations, on policy pursued by the government (Chell 2013). According to Cruz-González et al. (2014), environmental factors make the greatest influence for the selection of business direction. They can be assessed by behavioral analysis of customers, suppliers, competitors and research organizations, other companies, experts and consultants, professional associations, fairs, by information from exhibitions, conferences, scientific and trade/technical publications, patents. It should provide the answer whether these factors are favorable to start a business. People have better opportunity to start a business in that economic sector (industry), which is at the beginning of the life cycle (Waldner et al. 2015). The choice of business direction is often influenced by the individual characteristic of the new entrepreneur, good knowledge of some area, experience; opportunities to express 
their skills also are important in this case (Gao, Hafsi 2015). For example, an enterprising medical doctor usually organizes business in the medical field, not in others.

After selecting the most suitable business direction, it is necessary to examine possibilities for activities in the selected area (Markantoni et al. 2013; Moon 2014; Su, Gargeya 2016). It is also crucial to assess the situation on that market, and only then evaluate personal ability and potential to start a business in the determined area. One of the proper research methods is the SWOT analysis (Helms et al. 2011). According to Antony (2012), SWOT analysis is a strategic-level analysis and stands for strengths, weaknesses, opportunities and threats. It is a method of analyzing business processes, its resources, and its environment. Some indicators, showing the problems of society development, or disappointing indicators can also be as a source of ideas for a new business beginning. The SWOT analysis can serve as a basis for deciding on a future activity.

After the assessment of strengths and weaknesses, as well as opportunities and threats of selected activities, the rational next step would include more precise modeling actions of future performance with further assessment of business possibilities. In any case, a selected activity should not necessarily be a profit driven one; it can be socially responsible and contribute to the overall development of social prosperity. It means that tasks and steps of further activities may be different, and their content depends on the generated business objectives and possible measures of their implementation. Net planning may be a tool for finding solutions to these tasks (Ball 2011; Cole 2015).

Therefore, benevolence assessment would consist of the following tasks: general assessment of business conditions benevolence for creation of any business in a certain country, evaluation of development conditions for the selected kind business, assessment of competitive conditions for developing the chosen activity in a selected market, and determination of more detailed procedures and possibilities for market penetration.

\section{Empirical study of search for market penetration possibilities}

As in the case at issue Lithuania is a home country, it is appropriate to choose it for the analysis. It should be noted that Lithuania has made substantial progress in facilitating new businesses establishments. However, if further research shows inappropriateness of business conditions in Lithuania, then possibilities should be sought for building business in nearby countries.

\subsection{Assessment of benevolence of business conditions in Lithuania}

According to the World Bank study "Doing Business" (2015), Lithuania remains one of the most favored world countries in terms of possibilities to start business. Also, according to Doing Business 2015, Lithuania ranks 10th among the EU-28. And according to the joint world ranking, Lithuania takes the 24th place out of 189 countries.

After simplifying business start-up procedures, Lithuania succeeded to maintain a high 11th place in terms of business start rate. Lithuania is ahead of Belgium, Estonia, Latvia, Poland, France and some other EU countries. 
The Global Competitiveness Report 2014-2015 of the World Economic Forum fairly well assesses Lithuania with regard to inflation change (1), flexibility of wage determination (8), foreign direct investment and new technologies implementation (7), women's employment (13), prevention of HIV diseases (1). However, ranks the lowest among 144 countries of the world by the following indicators: country's ability to attract talents (125), recruitment and dismissal practices (124), and the country's ability to retain talent (129). Figure 1 shows the Lithuanian competitiveness index change.

When answering the 2014-2015 global competitiveness survey questionnaires about the circumstances which prevent from business development, even $17.2 \%$ of Lithuanian businessmen mentioned "inefficient government bureaucracy". "The level of taxes" and "decline in labor force" were the second and third most popular answers. According to the ratings published in the World Competitiveness Yearbook (IMD ... 2015), Lithuania ranked event 34th. Government efficiency and economic indicators went up in the Lithuanian competitiveness rating criteria, while infrastructure and business sector efficiency were down (Fig. 2).

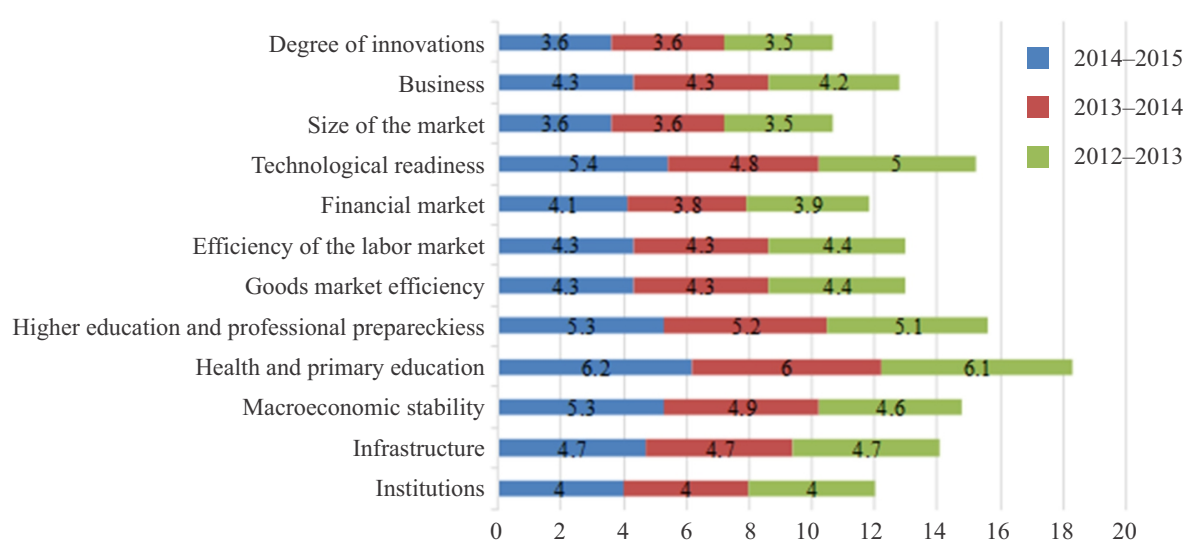

Fig. 1. Dynamics of Lithuanian competitiveness index criteria (according to Global

Competitiveness Report 2012-2013, Global Competitiveness Report 2013-2014 and Global Competitiveness Report 2014-2015)

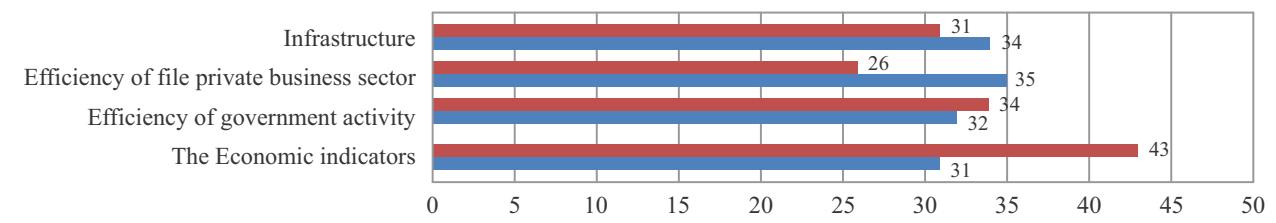

\begin{tabular}{|c|c|c|c|c|}
\cline { 2 - 4 } \multicolumn{1}{c|}{} & $\begin{array}{c}\text { The Econonic } \\
\text { indicators }\end{array}$ & $\begin{array}{c}\text { Efficiency of } \\
\text { goverment activity }\end{array}$ & $\begin{array}{c}\text { Effiaency ofthe private } \\
\text { business sector }\end{array}$ & Infrastructure \\
\hline 2014 & 43 & 34 & 26 & 31 \\
\hline 2015 & 31 & 32 & 35 & 34 \\
\hline
\end{tabular}

Position of Lithuania among 160 countries

Fig. 2. Dynamics of the Lithuanian competitiveness rating criteria (according to IMD World Competitiveness Center) 
US economic research organization "Heritage Foundation" has published new world economic freedom indexes. According to them, during the last year Lithuania went up by many positions being ranked the 15 th out of 178 countries in total.

The most serious difficulties are encountered in the areas of labor freedom, property rights freedom, and control of public spending. However, this freedom index has significantly improved in recent years. Low anticorruption freedom score shows that Lithuania has fairly high level of corruption. This is not a good indicator for individuals, particularly if they seek possibilities to start a business. Table 1 summarizes information about Lithuania's and neighboring countries' position in the rating for the benevolence of business environment.

Another standard index which represents the benevolence of business environment is the economic freedom index. Changes in indicators for the Lithuania's economic freedom index over 2013-2015 is shown in Figure 3. The index of economic freedom consists of a number of sub-variables.

The next step is identification of opportunities and threats. The results of SWOT analysis will enable making a better decision whether it is worth to start a business in Lithuania. A general analysis of the Lithuanian business environment allows a better understanding of the real competitive situation in Lithuania (Table 2).

Table 1. Information about ratings of business conditions

\begin{tabular}{lcccc}
\hline & $\begin{array}{c}\text { Index of business } \\
\text { conditions }\end{array}$ & $\begin{array}{c}\text { Global Index of } \\
\text { competitiveness }\end{array}$ & $\begin{array}{c}\text { Competitiveness } \\
\text { rating }\end{array}$ & $\begin{array}{c}\text { The index of } \\
\text { economic freedom }\end{array}$ \\
\hline Lithuania & 24 & 41 & 34 & 15 \\
\hline Latvia & 23 & 42 & 35 & 37 \\
\hline Estonia & 17 & 29 & 30 & 8 \\
\hline Poland & 32 & 43 & 36 & 39 \\
\hline
\end{tabular}

Source: created by the authors.

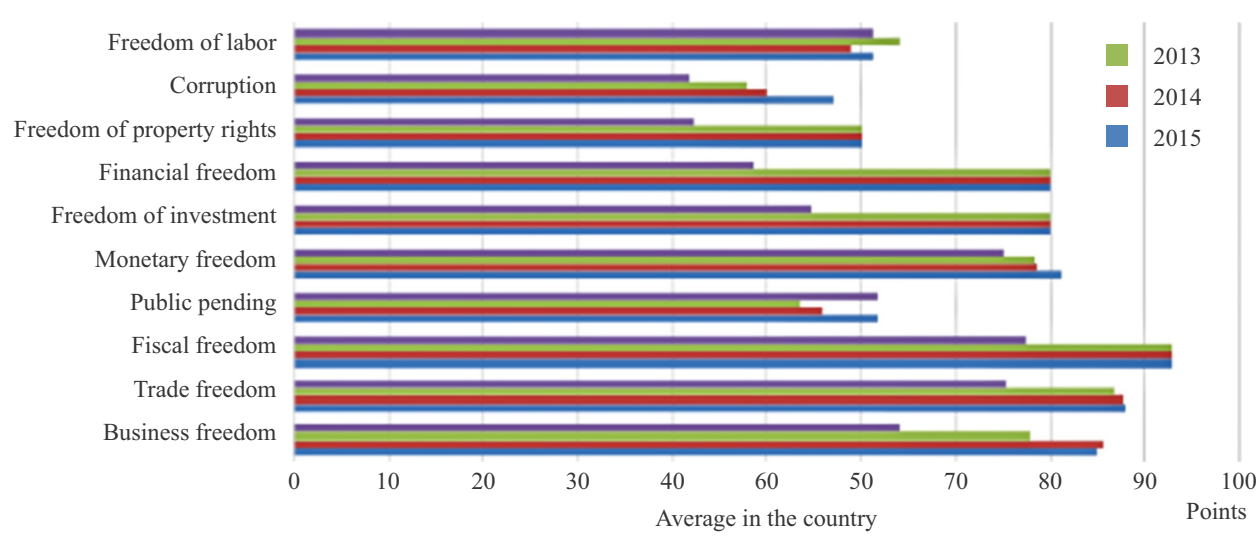

Fig. 3. Dynamics of Lithuania's economic freedom index in points (according to Heritage Foundation Report “2013, 2014, 2015 Index of Economic Freedom”) 
Table 2. Opportunities and threats of the Lithuanian business environment

\begin{tabular}{|c|c|}
\hline Opportunities & Threats \\
\hline $\begin{array}{l}\text { - Strategically convenient geopolitical } \\
\text { situation } \\
\text { Due to its unique geographical location, the } \\
\text { country can be considered as a potential } \\
\text { corridor ("bridge") between both East-West } \\
\text { and North-South. }\end{array}$ & $\begin{array}{l}\text { - Inflexible employment regulation system. } \\
\text { Over the past year, labor law has undergone } \\
\text { important changes, but has remained picky and } \\
\text { exaggerated in regulation of labor relations. } \\
\text { There are difficulties in relation to appointment } \\
\text { and dismissal of staff. }\end{array}$ \\
\hline $\begin{array}{l}\text { - Well-developed infrastructure } \\
\text { According to the World Bank's study (2014, } \\
\text { 2015), infrastructure in Lithuania is among } \\
\text { the best in the Baltic countries with well- } \\
\text { developed land, air and water transport. }\end{array}$ & $\begin{array}{l}\text { - Insufficiently developed sectors of high } \\
\text { and medium-high technologies } \\
\text { Their created added value in the comparative } \\
\text { share of manufacturing value added is low. } \\
\text { - High level of the shadow economy }\end{array}$ \\
\hline $\begin{array}{l}\text { - Qualified and competitive workforce } \\
\text { Lithuanian citizens are among the most } \\
\text { educated in Europe: Lithuania is among the } \\
\text { leaders in the EU in terms of percentage of } \\
\text { population with higher education. }\end{array}$ & $\begin{array}{l}\text { The shadow economy still accounts for a } \\
\text { significant share of GDP. It does not create } \\
\text { a transparent and competitive business } \\
\text { environment scale. } \\
\text { - Unstable legislative base }\end{array}$ \\
\hline $\begin{array}{l}\text { - Market attractiveness } \\
\text { The market is not completely saturated with } \\
\text { goods and services; there is also Western } \\
\text { culture, tolerance. }\end{array}$ & $\begin{array}{l}\text { Changing the laws regulating business } \\
\text { obligations does not increase investor } \\
\text { confidence. It is difficult for entrepreneurs to } \\
\text { predict what taxes are likely to increase in the } \\
\text { future. }\end{array}$ \\
\hline $\begin{array}{l}\text { - Favorable conditions for business start-up } \\
\text { According to the World Bank's study ( } 2014 \text {, } \\
\text { 2015), Lithuania ranks as high as the } 11 \text { th } \\
\text { in the world for business start-up conditions. } \\
\text { Lithuania is classified as "almost free" by the } \\
\text { economic freedom index criteria "business } \\
\text { freedom". }\end{array}$ & $\begin{array}{l}\text { Comparatively high level of corruption } \\
\text { This condition negatively affects investors and } \\
\text { restricts economic freedom. }\end{array}$ \\
\hline
\end{tabular}

Source: developed by the authors.

The government of Lithuania is actively working towards easing business conditions. Coupled with the results of the assessment, this leads to the conclusion that business conditions are favorable enough in Lithuania.

\subsection{Determination of business direction (kind)}

First of all, the search of business niche was carried out according to the analysis of data from the Department of Lithuanian Statistics (LDS), public information available from the Lithuanian State Labor Inspectorate (SLI) and other statistical documents. Attention could be paid to some rediscovered data. According to the information from the LDS, in 2015, there were even 93,017 enterprises in Lithuania. According to the information provided by the State Labor Inspectorate, there were even 3292 accidents at work in 2015 of which 3115 were light, 117 serious and 60 fatal accidents. Dynamics of the number of accidents during the last 5 years is also not encouraging, because most of the accidents occurred due to actual violation of occupational safety and health rules and standards. Broken down by economic activities, most violations were found in providing occupational safety and health $(\mathrm{OSH})$ services in construction $(28.7 \%)$, manufacturing $(27.7 \%)$ and trade $(9.2 \%)$ sectors. 
The situation above clearly shows that the problem does exist and it is paid insufficient attention. Although Lithuanian laws call for the need to use safety and health measures in an effective manner, the above-presented information obviously raises concerns about occupational safety conditions in Lithuania and the level of defense of public interest. The reasons for such a situation include the lack of employers' knowledge and nonobservance of delegated statutory responsibilities. This brings up the idea of establishing a dedicated company which would rectify the situation providing OSH services. Activities of such company could include preventive measures to protect workers from injuries and occupational diseases.

Today there is a clear desire on the part of employers desire to excel not only in the field of business, but also in providing a safe environment for employees due to the need to attract and retain the best of them. Not all employees work in safe and harmful working conditions yet. So, appropriate OSH services should be relevant to each employer.

According to the LDS data, occupational diseases increased approximately by $10 \%$ from 2011 to 2015. This fact also indicates possibly inappropriate working conditions in some Lithuanian organizations. It implies the need for high-quality OSH services.

\subsection{Competitive ability assessment of OSH services business}

The analysis of legal rules governing OSH services suggests that OSH services can be provided both by individuals and legal entities. However, they are subject to attestation. OSH services business mainly depends on activities of other economic entities and their results, as OSH services are largely provided to legal persons, not to private individuals. According to the data of the LSD, profitability of this kind of services has been steadily increasing over the past years. It should be noted that positive changes are also seen in the labor market. At the end 2015, employers registered 19.5 thousand job vacancies, i.e. by 4 percent more than in 2014. Even annual inflation in accordance with the harmonized index of consumer prices was low and stable during a long period. All the mentioned circumstances can be viewed as a positive factor to start OSH commercial activity.

According to LSD data, in 2015, OSH services were provided by 55 legal entities and 13 individuals in Lithuania. The largest part of the companies provides risk assessment services, training and coaching procedures, issue of personal protective equipment procedures. Only a few companies provide emergency OSH services and also a few of them have established service packages. Most of OSH service providers are micro companies with 3-5 employees. Most of them even do not have their own website.

The results of the analysis also confirm the possibility to foothold in the OSH services market with new services, which are currently not provided by existing market participants or provided insufficiently.

Product quality and price are extremely important in this service sector. Assessment of the quality of OSH services is quite difficult, when there is not enough information. In order to assess the quality of services provided by competitors, data available on web- 
site "Rekvizitai.lt" were used. Companies using OSH services were interviewed about the quality of such services. The quality of OSH companies' activities was rated on a 1-10 scale where 10 points mean the highest quality and 1 means the lowest quality of $\mathrm{OSH}$ services. Figure 4 shows aggregated quality data of randomly selected $50 \mathrm{OSH}$ services companies.

$50 \%$ of the assessed OSH service companies' rating did not reach 6 points. On the other hand, none of the OSH service companies received the worst rating (1 point). Such favorable circumstances also suggest a possibility to penetrate the OSH services market by providing higher-quality services than that of competitors.

Rating of prices for OSH services is even more difficult. The price of services depends on customer's activities, customer's technology used, the number of workers and other factors. In order to estimate the price in the OSH service market, the telephone survey was performed with OSH service providers. In order to standardize and evaluate the services and their price more objectively, all OSH-service companies have been asked the same question, "How much would the service of occupational safety and performance of health service functions cost for some forestry company with 12 staff members?". The survey results are presented in Figure 5.

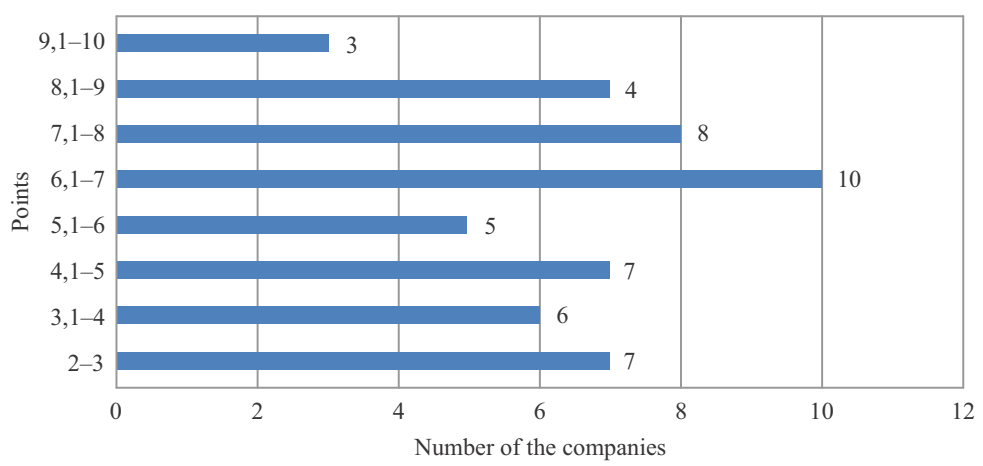

Fig. 4. Rating of OSH services companies

Source: developed by the authors in accordance with "Rekvizitai.lt", data of October 2015

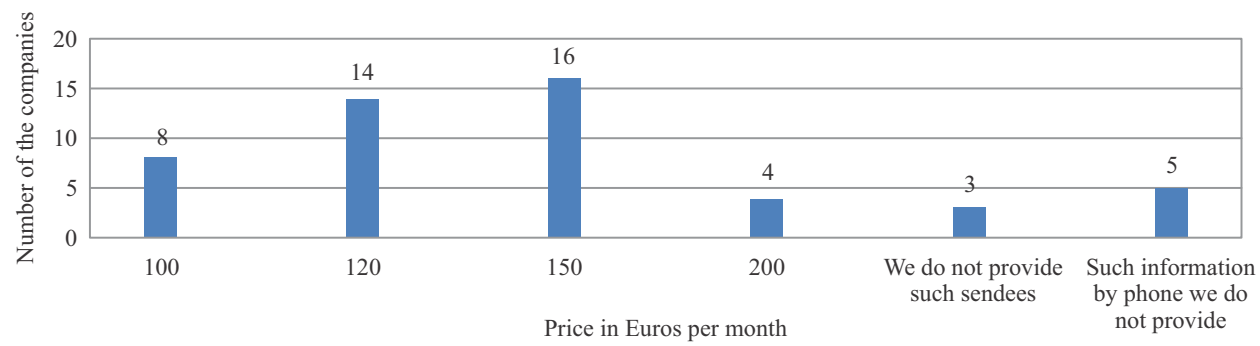

Fig. 5. Cost analysis of providing the service of OSH functions for the forestry company with 12 staff members (developed by the authors according to the 2015-2016 telephone survey data) 
The analysis of the past 5 years below was focused on dynamics of the number of OSH service providers and the number of enterprises using OSH services. The number of OSH service providers declined in 2011 and gradually reached the level of 2011 again in 2015. In 2015, OSH services were provided by 60 legal entities and 16 individuals. The growing total number of the companies (potential users) also indicates the existence of good possibilities for a new business in this area. Results' analysis did not deny the possibility of initiating OSH services business. Figure 6 shows the number of enterprises using OSH services by economic activities in 2015.

According to the data of the State Labor Inspectorate (SLI) for 2015, OSH services were used by 2601 legal entities and 69 individual persons (farmers, persons employed under individual activity certificates). Dynamics of OSH service users shows that the use of OSH services increased over the past few years, that the OSH service market is growing and that its full potential is not exhausted yet. The study also demonstrated that a possible OSH service niche could be in the transport, agriculture and construction sectors where provision of such services is not very popular yet.

In order to carry out a broader analysis of OSH service requirements, identification of customer satisfaction according to the quality of OSH services was made. As mentioned, in 2015, there were 93,017 economic entities operating in Lithuania. It was not possible to interview such a number of respondents. According to SLI data, the majority of fatal accidents occurred in the construction industry (27\% of all fatal accidents at work). Another study was conducted to interview managers in the building industry. Analysis of the data revealed that Lithuanian entrepreneurs face problems in ensuring compliance with "health and safety" requirements. This even more increases the need for solving these issues. The questionnaire was sent on 15 January 2016 to more than six thousand registered construction companies in Lithuania; answers were obtained from 860 respondents. The following findings were made: the majority (67\%) of the interviewed construction managers answered that they have to deal with difficulties in meeting OSH regulatory requirements. Even $350(62 \%)$ respondents said that the current OSH services, which are provided by private companies, do not meet their cost expectations.

The assessment of the answers in this survey also revealed that the quality of OSH services is not adequate to their price, given that most construction companies are fac-

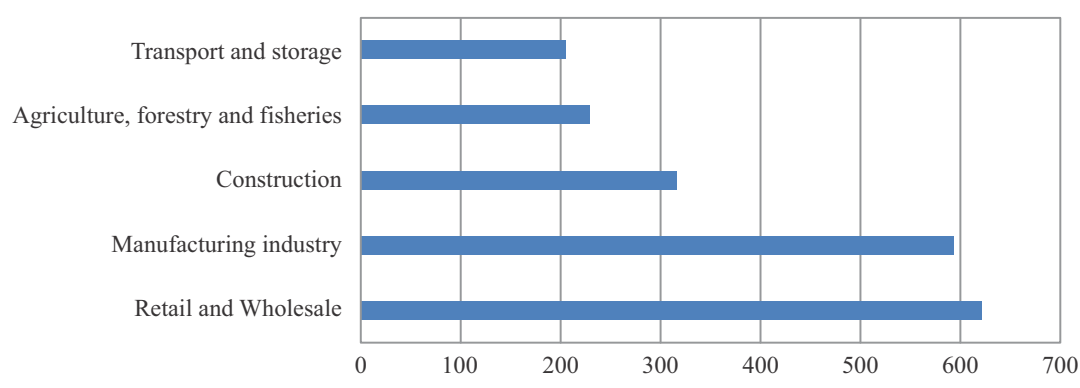

Fig. 6. Economic activities in which OSH services were provided Source: State Labor Inspectorate, 2015. 
ing difficulties in ensuring the "health and safety" requirements. The aforementioned arguments also show the need and possibility to begin an OSH service business. But a new company has to provide services of a better quality and attract current customers in that way.

\subsection{SWOT analysis of OSH service business}

SWOT analysis has revealed the real opportunities for start-ups and difficulties which they are likely to face in the process of starting OSH services business. At the same time, this analysis allows determining the ways for achieving goals and helps to evaluate alternative solutions and select the most appropriate of them. The analysis of the results is useful to model the directions for company's development. The results of the SWOT analysis are presented in Table 3.

Table 3. SWOT analysis of OSH services business (developed by the authors)

\begin{tabular}{|c|c|}
\hline Strengths & Weaknesses \\
\hline $\begin{array}{l}\text { 1. Providing OSH services does not require special } \\
\text { permits and high investments. } \\
\text { 2. Favorable proportion of investment and profit- } \\
\text { ability. } \\
\text { 3. Large market of potential users. } \\
\text { 4. Small number of competitors. } \\
\text { 5. Relatively low cost. } \\
\text { 6. Socially responsible business. }\end{array}$ & $\begin{array}{l}\text { 1. Poor OSH service quality. } \\
\text { 2. Poor reputation of OSH services companies. } \\
\text { 3. Disproportionate service quality and price } \\
\text { ratio. } \\
\text { 4. Lack of consultation on labor law issues. } \\
\text { 5. Service uncertainty. }\end{array}$ \\
\hline Opportunities & Threats \\
\hline $\begin{array}{l}\text { 1. Well-developed information technologies. } \\
\text { 2. A large number of occupational accidents and } \\
\text { diseases in Lithuania. } \\
\text { 3. Ability to expand rapidly due to the growing de- } \\
\text { mand for services. } \\
\text { 4. Cooperation with other companies by increasing } \\
\text { the number of services. } \\
\text { 5. Growing user needs for qualified OSH services. }\end{array}$ & $\begin{array}{l}\text { 1. Possibility of strong competitors from other } \\
\text { EU countries. } \\
\text { 2. Emigration of professional, skilled labor and } \\
\text { proactive people. } \\
\text { 3. Increasing cost of labor. } \\
\text { 4. Lack of flexibility of labor relations regula- } \\
\text { tory framework. } \\
\text { 5. The shadow economy. }\end{array}$ \\
\hline
\end{tabular}

The SWOT analysis of the OSH business area is important because it shows the real possibilities of a future company profile and allows assessment of possibilities for meeting company's objectives. The results will also help to justify decisions regarding protection against threats and to change weaknesses into new opportunities. After the evaluation of external and internal environments, it is rational to move to the formation of company's future strategy.

\subsection{Identification of strategic options for market penetration by OSH service companies}

The next rational step includes more precise modeling actions for future performance with assessment of their possibility. In this case, the strategic objective of an OSH company is regarded as an attempt to penetrate the existing market. The mission of such a company would be providing its activities only based on high qualification of 
employees, also on customers' and public trust, responsibility and professionalism in providing high quality OSH services in order to protect workers' health, life and working capacity while operating as a reliable partner. Such a mission may be fulfilled through some alternative strategic options. They can differ in terms of their content, consistency and quantity.

As mentioned above, the best instrument for that purpose is using net planning actions. Determining real options depends on many more factors, but benevolence of business

Table 4. Possible alternative sets of options for implementation of strategic objectives in OSH services company

\begin{tabular}{|c|c|c|c|c|}
\hline \multirow{2}{*}{ 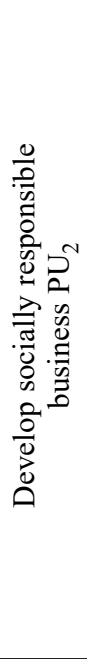 } & 1 & $\begin{array}{l}\text { Becoming a member of Lithuani- } \\
\text { an socially responsible business } \\
\text { association } \\
\text { Organizing investigations and oth- } \\
\text { er measures to improve die social } \\
\text { welfare of emploee } \\
\text { Implementation of work stand- } \\
\text { ardization procedures } \\
\text { Participation in community activi- } \\
\text { ties }\end{array}$ & $\begin{array}{l}\mathrm{PP}_{21} \\
\mathrm{PP}_{22} \\
\mathrm{PP}_{23} \\
\mathrm{PP}_{24}\end{array}$ & $\mathrm{PP}_{23}$ \\
\hline & 2 & $\begin{array}{l}\text { Becoming a member of Lithuani- } \\
\text { an socially responsible business } \\
\text { association } \\
\text { Organizing investigations and oth- } \\
\text { er measures to improve the social } \\
\text { welfare of emploee } \\
\text { Participation in community activi- } \\
\text { ties }\end{array}$ & $\begin{array}{l}\mathrm{PP}_{21} \\
\mathrm{PP}_{22} \\
\mathrm{PP}_{23}\end{array}$ & \\
\hline \multirow{2}{*}{ 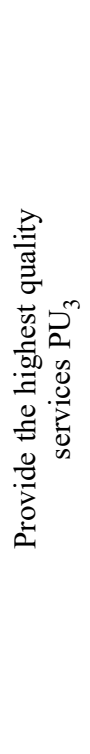 } & 1 & $\begin{array}{l}\text { Staff training and professional de- } \\
\text { velopment } \\
\text { Implementation measures for mo- } \\
\text { tivation } \\
\text { Implementation system of com- } \\
\text { petencies development and work } \\
\text { distribution } \\
\text { Audit function } \\
\text { Studies and other identified meas- } \\
\text { ures for ensure proper quality } \\
\text { analysis of service }\end{array}$ & $\begin{array}{l}\mathrm{PP}_{31} \\
\mathrm{PP}_{32} \\
\mathrm{PP}_{33}\end{array}$ & $\mathrm{PP}_{34}$ \\
\hline & 2 & $\begin{array}{l}\text { Staff training and professional de- } \\
\text { velopment } \\
\text { Implementation measures for mo- } \\
\text { tivation } \\
\text { Implementation system of com- } \\
\text { petencies development and work } \\
\text { distribution } \\
\text { Studies and other identified meas- } \\
\text { ures for ensure proper quality } \\
\text { analysis of service }\end{array}$ & $\begin{array}{l}\mathrm{PP}_{31} \\
\mathrm{PP}_{32} \\
\mathrm{PP}_{33}\end{array}$ & \\
\hline
\end{tabular}

Source: developed by the authors. 
conditions would be the main. Business conditions may also be affected by indirect factors such as climate, pollution, staff training opportunities, office location. The use of the net schedule for strategic alternative selection and composition can express not only the consistency of necessary actions, but also their potential impact on one or another factor and the necessary operations to prevent inappropriate results.

Some possible operations nay involve different sets of strategic options. Examples of the sets of strategic options, which are suitable for OSH service business, are shown in Table 4.

New OSH service businesses need to assess possibilities for the implementation of all strategic options and also the potential outcomes after implementing them. Results of such assessment will show which way is the best for OSH business newcomer.

The selected alternative is closely connected with reinforcement of factors for achieving strategic objective through effective distribution, rational use and development of the targeted company's potential.

\section{Conclusions}

Summarizing the scientific literature data, it can be argued that business viability is more or less dependent on business conditions. In order to assess benevolence of business conditions in the current situation before starting up a business, some measures are selected and techniques of their application are determined in this article. The proposed systematic methodology first requires searching for solutions to assessing general aspects which are then narrowed down to assessing more detailed aspects.

It was found that starting up a business requires a pre-assessment of the benevolence of business conditions in a home country. Such assessment can be based on information provided by the World Bank study "Doing Business" (2014, 2015) information, countries' Competitiveness Index of the World Economic Forum, answers in questionnaires of country's businessmen about business conditions, the Economic Freedom Index and results of the country's SWOT analysis.

After determining the country with the most favorable business conditions, the next step is to find a competitive business niche which would be suitable to perform the intended activities in the country. It is also necessary to assess the possibilities for developing the chosen kind of business.

The last step to be executed before starting a new business is the assessment of competitive ability of the chosen kind of business in the selected country. For this purpose, it is necessary to know the number of existing business entities, the number of potential customers, to assess the price and customers' satisfaction with the existing product quality. A SWOT analysis of the chosen activity is also necessary in order to identify long-term perspectives for practical work.

The results of the research were very positive for the OSH service area, but we are also aware of its limitations. Our further research should be directed to a different kind of services. If the methodology proves to be suitable for a different kind of services, then 
it will be possible to state that it is universal. As a matter of fact, the sequence and the content of the proposed actions are not incompatible with initiating other kinds of business. Our article does not fully explore the potential of applying the chosen strategy because of too many possibilities; these issues are to be addressed in future research, too.

The proposed methodology with the specified sequence of actions can help to design more objective and reasoned decisions for business beginners in starting up a new commercial activity. This methodology is also suitable to be used by business incumbents who seek to expand their business and look for new business development directions. The proposed methodology will help to overcome many challenges and avoid ineffective expenditure.

\section{References}

Adomako, S.; Danso, A. 2014. Regulatory environment, environmental dynamism, political ties, and performance, Journal of Small Business and Enterprise Development 21(2): 212-230.

https://doi.org/10.1108/JSBED-01-2014-0004

Akpinar, M.; Can, O.; Mermercioglu, M. 2017. Assessing the sources of competitiveness of US states, Competitiveness Review: An International Business Journal 27(2): 161-178.

https://doi.org/10.1108/CR-02-2016-0014

Akram, M. Ch.; Faheem, A. M.; Dost, M. K. B.; Iqra, A. 2011. Globalization and its impact on the world economic development, International Journal of Business and Social Science 2(23): 291-297.

Antony, J. 2012. A SWOT analysis on Six Sigma: some perspectives from leading academics and practitioners, International Journal of Productivity and Performance Management 61(6): 691-698. https://doi.org/10.1108/17410401211249229

Aruoba, S. B.; Diebold, F. X.; Scotti, C. 2012. Real-time measurement of business conditions, Journal of Business \& Economic Statistics 27(4): 417-427. https://doi.org/10.1198/jbes.2009.07205 Ball, M. 2011. Planning delay and the responsiveness of English housing supply, Urban Studies 48(2): 349-362.

Chell, E. 2013. Review of skill and the entrepreneurial process, International Journal of Entrepreneurial Behaviour \& Research 19(1): 6-31. https://doi.org/10.1108/13552551311299233

Blank, S.; Dorf, B. 2012. The startup owner's manual: the step-by-step guide for building a great company. California: K\&S Ranch Publishing Division.

Cole, S. 2015. Space tourism: prospects, positioning, and planning, Journal of Tourism Futures 1(2): 131-140. https://doi.org/10.1108/JTF-12-2014-0014

Cruz-González, J.; López-Sáez, P.; Navas-López, J. E.; Delgado-Verde, M. 2014. Directions of external knowledge search: investigating their different impact on firm performance in hightechnology industries, Journal of Knowledge Management 18(5): 847-866.

https://doi.org/10.1108/JKM-06-2014-0243

Daryanto, A.; Khan, H.; Matlay, H.; Chakrabarti, R. 2013. Adoption of country-specific business websites, Journal of Small Business and Enterprise Development 20(3): 650-660.

https://doi.org/10.1108/JSBED-04-2013-0048

Feinleib, D. 2012. Why startups fail and how yours can succeed. USA: Apress.

https://doi.org/10.1007/978-1-4302-4141-6

Gao, Y.; Hafsi, T. 2015. R\&D spending among Chinese SMEs: the role of business owners' characteristics, Management Decision 53(8): 1714-1735. https://doi.org/10.1108/MD-04-2014-0208 
Gammeltoft, P.; Pradhan, J. P.; Goldstein, A. 2010. Emerging multinationals: home and host country determinants and outcomes, International Journal of Emerging Markets 5(3/4): 254-265. https://doi.org/10.1108/17468801011058370

Hamlin, R.; Henry, J.; Cuthbert, R. 2012. Acquiring market flexibility via niche portfolios, European Journal of Marketing 46(10): 1302-1319. https://doi.org/10.1108/03090561211248044

Helmers, C.; Rogers, M. 2010. Innovation and the survival of sew firms in the UK, Review of Industrial Organization 36(3): 227-248.

Helms, M. M.; Rodríguez, M. A.; Lisandro de los Ríos, W. H. 2011. Entrepreneurial potential in Argentina: a SWOT analysis, Competitiveness Review: An International Business Journal 21(3): 269-287. https://doi.org/10.1108/10595421111134859

Heritage Foundation. 2015 Index of Economic Freedom [online], [cited 15 July 2016]. Available from Internet: http://www.heritage.org/index/pdf/2015/book/index_2015.pdf.

Heritage Foundation. 2014 Index of Economic Freedom [online], [cited 15 July 2016]. Available from Internet: http://www.heritage.org/index/pdf/2014/book/index_2014.pdf.

Heritage Foundation. 2013 Index of Economic Freedom [online], [cited 15 July 2016]. Available from Internet: http://www.heritage.org/index/pdf/2013/book/index_2013.pdf.

IMD World Competitiveness Center. 2015. IMD World Competitiveness Yearbook [online], [cited 15 July 2016]. Available from Internet: http://www.imd.org/wcc/world-competitiveness-centerrankings/world-competitiveness-yearbook-ranking/.

Kandel, E.; Leshchinskii, D.; Yuklea, H. 2011. VC Funds: aging brings Myopia, Journal of Financial and Quantitative Analysis 46(2): 431-457.

Ketels, C. 2013. Recent research on competitiveness and clusters: what are the implications for regional policy?, Cambridge Journal of Regions Economy and Society 6(2): 269-284.

https://doi.org/10.1093/cjres/rst008

Krämer, A.; Jung, M.; Burgartz, T. 2016. A small step from price competition to price war: understanding causes, effects and possible countermeasures, International Business Research 9(3): 2-13. https://doi.org/10.5539/ibr.v9n3p1

Kurzynski, M. 2012. Peter Drucker: modern day Aristotle for the business community, Journal of Management History 18(1): 6-23. https://doi.org/10.1108/17511341211188628

Lithuanian State Labor Inspect (SLI). 2015. Statistics of accidents at work [online] [cited on 15 July 2016]. Available from Internet: https://www.vdi.lt/Forms/Tekstas1.aspx?Tekstai_ID=746

Lithuanian Statistics Department (LSD). 2015. Bankruptcy of companies [online], [cited 15 June 2016]. Official Statistics Portal. Available from Internet: https://osp.stat.gov.lt/informaciniaipranesimai? articleId $=3927220$

Lithuanian Economy Ministry (LEM). 2014. Lithuania Entrepreneurship Action Plan for years 2014-2020 [online], [cited 15 June 2016]. Available from Internet: http://ukmin.lrv.lt/uploads/ ukmin/documents/files/Verslumo_veiksmų_planas_2014-2020_1.pdf

Markantoni, M.; Strijker, D.; Koster, S. 2013. Growth expectations for side activities in rural areas, Journal of Small Business and Enterprise Development 20(3): 584-602.

https://doi.org/10.1108/JSBED-04-2013-0060

Mitzner, D. 2016. Sweden is a tech superstar from North [online], [cited 5 April 2016]. Available from Internet: https://techcrunch.com/2016/01/26/sweden-is-a-tech-superstar-from-the-north/

Moon, S. 2014. How does the use of external knowledge influence innovative performance of service firm an introductory study of openness and service innovation, Seoul Journal of Business 20(1): 35-61.

Onel, N.; Avinandan Mukherjee, A. 2015. Understanding environmentally sensitive consumer behaviour: an integrative research perspective, World Journal of Entrepreneurship, Management and Sustainable Development 11(1): 2-16. https://doi.org/10.1108/WJEMSD-07-2014-0021 
Panagiotakopoulos, A. 2013. Mina makes the most of human-resource management: mini-market switches from competing on price to competing on service, Human Resource Management International Digest 21(1): 26-27. https://doi.org/10.1108/09670731311296474

RAIT. 2014. A country of intrapreneurs with an increasing number of opportunity-driven ventures [online], [cited on 15 July 2016]. Available from Internet: http://www.gemconsortium.org/ country-profile/82

Rekvizitai.lt The directory of Lithuanian companies [online], [cited on 15 July 2016]. Available from Internet: http://rekvizitai.vz.lt/en/

Samoška, M. 2011. Analysis of business environment evaluation methods, Business in XXI Century 3(4): 28-89.

Soltes, V.; Stofkova, K. R. 2016. Impact of business environment on regional disparities, in $C B U$ International Conference on Innovations in Science and Education (CBUIC), 23-25 March 2016, Prague, Check Republic, 187-191. https://doi.org/10.12955/cbup.v4.760

Su, J.; Gargeya, V. B. 2016. Supplier selection in small- and medium-sized firms. The case of the US textile and apparel industry, American Journal of Business 31(4): 166-186.

https://doi.org/10.1108/AJB-12-2015-0037

Szkorupová, Z. 2015. Relationship between foreign direct investment and domestic investment in selected countries of Central and Eastern Europe, Procedia Economics and Finance 23:10171022. https://doi.org/10.1016/S2212-5671(15)00350-0

Waldner, F; Poetz, M. K.; Grimpe, C.; Eurich, M. 2015. Antecedents and consequences of business model innovation: the role of industry structure, in C. Baden-Fuller, V. Mangematin (Eds.) Business models and modelling: advances in strategic management. Vol. 33. Brentford: Emerald Group Publishing Limited, 347-386.

World Bank. 2014. Doing business. Understanding Regulations for Small and Medium-Size Enterprises. The World Bank Report [online], [cited 15 July, 2016]. Available from Internet: http:// www.doingbusiness.org/reports/global-reports/doing-business-2014

World Bank. 2015. Doing business. Going Beyond Efficiency. The World Bank Report [online], [cited 15 July, 2016]. Available from Internet: http://www.doingbusiness.org/reports/global-reports/doing-business-2015

World Economic Forum. 2014. The Global Competitiveness Report 2014-2015. World Economic Forum Insight Report [online], [cited 15 July 2016]. Available from Internet: http://www3.weforum.org/docs/WEF_GlobalCompetitivenessReport_2014-15.pdf

World Economic Forum. 2013. The Global Competitiveness Report 2013-2014. World Economic Forum Insight Report [online], [cited 15 July 2016]. Available from Internet: http://www3.weforum.org/docs/WEF_GlobalCompetitivenessReport_2013-14.pdf

World Economic Forum. 2012. The Global Competitiveness Report 2012-2013. World Economic Forum Insight Report [online], [cited 15 July 2016]. Available from Internet: http://www3.weforum.org/docs/WEF_GlobalCompetitivenessReport_2012-13.pdf

Zoltan, J. A.; Szerb, L.; Autio, E. 2015. Global Entrepreneurship Index [online], [cited on 15 July 2016]. Available from Internet: http://redit.skane.com/sites/default/files/media/document/ gei_2015.pdf

Živilè TUNČIKIENĖ is Associate Professor at the Department of Social Economics and Business Management, Faculty of Business Management, Vilnius Gediminas Technical University. Research interests: management of socioeconomic development, strategic management of public sector, environmental assessment for ease of doing business.

Rolandas DREJERIS is Associate Professor at the Department of Social Economics and Business Management, Faculty of Business Management, Vilnius Gediminas Technical University. Research interests: innovation management, business strategy, process of services development, quantitative research of business environment. 